This Journal is available in Telkom University online Journals

Jurnal Manajemen Indonesia

\title{
Assessing Customer Satisfaction: A Case in Logistics Service Company
}

M. Mujiya Ulkhaq ${ }^{1}$, Samuel H. Pandiangan ${ }^{2}$, Elieser L. Tarigan ${ }^{3}$, Abdi R. Silalahi ${ }^{4}$, and Septina G. Lumbantobing ${ }^{5}$ 1,2,3,4,5 Department of Industrial Engineering, Diponegoro University, Indonesia

\begin{abstract}
This study aims to assess customer satisfaction of a logistics service company in Indonesia. Several research employed the classical importance-performance analysis (IPA) to accomplish the objective; instead, this research used importance performance competitor analysis (IPCA). IPCA is considered as a remedy for IPA since the later has been criticized for several reasons, e.g., the relative structure of IPA and its lack of competitors' consideration. A case study has been conducted to show the applicability of IPCA. Result shows that several service attributes must be improved since they have lower performance than the competitor. Recommendations that can be done as a part to continuous improvement were provided. Finally, we also show that using IPAwithout considering the competitor - would bring the management to a misleading interpretation.
\end{abstract}

Keywords-Customer satisfaction; importance performance competitor analysis; logistics service

\begin{abstract}
Abstrak
Penelitian ini bertujuan untuk menilai kepuasan pelanggan pada perusahaan jasa logistik di Indonesia. Beberapa penelitian menggunakan analisis kepentingan-kinerja klasik (IPA) untuk mencapai tujuan; sebagai gantinya, penelitian ini menggunakan analisis kepentingan kinerja pesaing (IPCA). IPCA dianggap sebagai obat untuk IPA karena kemudian telah dikritik karena beberapa alasan, misalnya, struktur relatif IPA dan kurangnya pertimbangan pesaing. Sebuah studi kasus telah dilakukan untuk menunjukkan penerapan IPCA. Hasil penelitian menunjukkan bahwa beberapa atribut layanan harus ditingkatkan karena memiliki kinerja yang lebih rendah dari pesaing. Rekomendasi yang dapat dilakukan sebagai bagian dari perbaikan berkelanjutan telah diberikan. Terakhir, kami juga menunjukkan bahwa menggunakan IPA — tanpa mempertimbangkan pesaing — akan membawa manajemen pada interpretasi yang menyesatkan.
\end{abstract}

Kata kunci-Kepuasan Pelanggan; Pentingnya Analisis Kinerja Pesaing; Layanan Logistik

\section{INTRODUCTION}

Manufacturing, which can be defined as the process of converting raw materials into finished goods using human labor and machinery, plays a vital role in supporting human life (Chryssolouris, 2013; Ruiz-de-ArbuloLopez et al., 2013). The finished goods must be delivered to appropriate destinations, i.e., the customers, so that the values could be enabled. The process of delivering such finished goods is arguably referred to logistics. Broadly speaking, logistics is described as a management of flow of goods from a location (or point) to another point to fulfill the needs of customers (Christopher, 1998).

Currently, most manufacturing companies rely on third-party logistics (3PL) companies to distribute the goods to different areas due to several reasons, such as budget limitation and time constraint. 3PL companies nowadays face fierce competition. Based on the study of Langley (2012) that cross-examined 2,342 industry executives across the globe, the total incomes of 3PL companies increase steadily, with $65 \%$ of shippers rising their partnership with 3PL companies. In addition, $56 \%$ of the respondents said that their partnerships with 3PL services 
have led to incremental profits. It implies also that the customers (or partners) of 3PL companies are continuously increasing the requirements because they are aware about the quality the competitors of their partners. As a result of this struggle, 3PL companies must be more aware of customer satisfaction since it precedes customer loyalty and could lead to repeat customer purchase behavior (Cronin and Taylor, 1992; Ladhari et al., 2008) that could generate high incomes (Luo and Homburg, 2007).

Customer satisfaction is considered as a function of performance of different service attributes, i.e., the consequence of realization of (both explicit and implicit) customer needs (Tontini and Silveira, 2007). Some classical literatures stated that consumer satisfaction is a function of importance of such attributes and their performances (e.g., Myers and Alpers, 1968; Swan and Coombs, 1976). Not surprisingly, the importanceperformance analysis (IPA) by Martilla and James (1977) has become a popular managerial tool for assessing and evaluating customer satisfaction. IPA is considered as simple, easy to be implemented and interpreted. Some scholars applied the method to find out the attributes which perform well and or must be enhanced (e.g., Astari et al., 2020; Pramono et al., 2017; Rasyida et al., 2016; Ulkhaq et al., 2017, 2019a, 2019b). Although IPA is popular due to its simplicity, the applicability has certain limitations due to the relative structure as well as lack of the consideration of competitors (see the Section 2.2. for a brief explanation).

The importance performance competitor analysis (IPCA) by Albayrak (2015) is regarded as a remedy for the classical IPA. The method utilizes absolute structure (as an alternative to relative structure) as well as considering the competitor, making it preferable to classical IPA (see Section 2.2 for more elaboration). Despite the superiority of IPCA, its application remains limited (as the best of our knowledge, it has been implemented only to evaluate customer satisfaction in hospitality sector (e.g., Albayrak, 2015; Albayrak et al., 2018; Caber et al., 2017). Therefore, this research tried to widen the use of IPCA to logistics service sector. To show the implementation, a case study has been conducted to assess customer satisfaction of an Indonesian-based logistics service company.

\section{RESEARCH DESIGN}

To assess and analyze customer satisfaction of logistics service company, five dimensions were adapted and modified from classical SERVQUAL scale (Parasuraman et al., 1988), which have been widely applied to describe attributes in service setting. They are tangibles, reliability, responsiveness, assurance, and empathy. These five dimensions which consist of 18 attributes are described in Subsection 2.1, while the method used, i.e., IPCA, is explained in Subsection 2.2.

\section{A. Dimensions and Attributes}

The first dimension is tangibles; it refers to the appearance of the personnel, the equipment, or physical facilities. In this sense, this first dimension refers to the physically viable aspects of the employees and the building (as well as interior design) of the logistics service company. Tangibles has four attributes, i.e., the logistics service company has cleaned and comfortable facilities, including waiting room and toilet (TAN1); the employees appear neat and well dressed (TAN2); the company has reliable equipment, including set of scales and desktop computer (TAN3); and the equipment used are up to date (TAN4).

The second dimension is reliability, which refers to the ability to deliver the service accurately and dependably. It implies that the company delivers its services to the customers on its promises, such as about the service provision, delivery, pricing, as well as problem resolutions. It constitutes four attributes, i.e., when the company promises to do such thing by a certain a time, it does so (REL1); the company does not make any mistake related to destination delivery charge and weights of the freight (REL2); the company keeps its records accurately, including having tracking feature (REL3); and there are several options or alternatives that can be chosen (REL4).

Responsiveness as the third dimension is defined as the willingness to giving help to the customers and providing quick service. It emphasizes promptness and attentiveness in managing what customers want, including their needs, their questions, as well as handling their complaints and problems. It has four attributes, i.e., the company takes care of problems quickly (RES1); the staff always help the customers (RES2); the company will tell the customers if any problem occurs (RES3); and the customers receive prompt service from the employees (RES4).

The fourth dimension is assurance. It refers to the staff' knowledge or understanding as well as the ability of the company and its staff to inspire believe and confidence to the customers. It has three attributes as follows, i.e., 
the company has insurance option (ASS1), the company calibrates its set of scales to maintain the accuracy (ASS2), and the company keeps the condition of the items delivered unchanged (ASS3).

The last dimension, empathy, is defined as the ease of relationships, personal attention, good communication, and understanding the needs of the customers. It has three attributes, i.e., the employee does give individual or personal attention to the customers (EMP1), the location of the company is strategically convenient (EMP2), and the company provides customer contact that can be easily reached (EMP3).

\section{B. Importance Performance Competitor Analysis}

IPA has been widely employed to assess customer satisfaction related to importance and performance of service attributes in many research areas, including education (e.g., Silva and Fernandes, 2010), airlines and airport (e.g., Rasyida et al., 2016), tourism (e.g., Lai and Hitchcock, 2015; Astari et al., 2020), e-commerce (Ulkhaq et al., 2017, 2019a, 2019b), banking (e.g., Yu, 2008), and health (e.g., Hawes and Rao, 1985). However, scholars have criticized IPA despite its popularity, inexpensive to implement, and easy to interpret as follows.

IPA uses self-stated method to assess and analyze the importance and performance of service attributes. This method could lead to inappropriate (as well as subjective) service attribute positioning. Crompton and Duray (1985) on the other hand, suggested to use statistical method to obtain the values to give more accurate results. Next, IPA is criticized due to the possible connection between performance and importance. IPA assumes those two variables are not interrelated; however, some studies show that these variables are not independent (Oh, 2001; Sampsona and Showalter, 1999). In dividing the quadrants, IPA uses relative structured. It means that when the importance or performance of any attribute is changed, the grand mean that determines the cut-off point (or the crosshairs) of the axes, will also alter. This structure makes the IPA diagram to be relative. Bacon (2003) recommended the diagonal model rather than quadrant model that has absolute structured. In a diagonal model, in any case where there is a lower performance than importance, the service attributes that must be focused on are pointed out (Abalo et al., 2007). Finally, IPA is criticized because it lacks consideration of competitors (Chen, 2014; Mikulić and Prebežac, 2012). Keyt et al (1994) stated that competitive advantages should be established relative to the competitors. Nevertheless, IPA only utilizes the importance performance of the company without considering its competitors. Due to fierce competition recently, it is vital to be aware of competitors' information as a supplement to the importance of such service attributes.

IPCA which is proposed by Albayrak (2015) has an ability to handle IPA's criticisms. Basically, it is generated by the presence of competitor's information in the diagonal model. While IPA diagram has four quadrants, in which the horizontal axis is the performance and the vertical axis is the importance (see Fig. 1a), IPCA diagramsimilar to IPA in which has four quadrants, yet the vertical axis denotes the gap, and the horizontal axis is measured performance difference (see Fig. 1b). The gap of attribute $i \mathrm{Gap}_{i}$, can be calculated as: Gap $\mathrm{p}_{i}=\mathrm{P}_{i}-\mathrm{I}_{i}$, where $\mathrm{P}_{i}$ is the performance score of the focal company for attribute $i$ and $\mathrm{I}_{i}$ is the importance score for attribute $i$. Intuitively, negative gap indicated importance score which is higher than the performance, whereas conversely, lower performance score than performance score means a positive gap. An attribute which has performance score equals to importance score is located on the so-called "iso priority line". This gap measurement is preferred in the service quality studies (Bacon 2003; Beldona and Cobanoglu, 2007; Tonge and Moore, 2007). The horizontal axis of IPCA is performance difference (PD). PD for attribute $i \mathrm{PD}_{i}$, can be obtained by $\mathrm{PD}_{i}=\mathrm{P}_{i}-\mathrm{PC}_{i}$, where $\mathrm{PC}_{i}$ is the performance score of the competitor for attribute $i$. If the competitor's performance is lower than the focal company, it means a positive difference, whereas when the focal company's performance is lower than the competitor, the difference will be negative. IPCA is considered has absolute structured since the crosshairs located in zero points (both for horizontal and vertical axes), whereas IPA is a relative structure since its crosshairs are the grand means of the performance and importance average scores.

There are four quadrants in IPCA diagram. The first quadrant is in north-east, named solid competitive advantage. Attributes located in this quadrant both have high (positive) gap scores and high (positive) performance difference scores. It means that the focal company has better performance than its competitor, indicating that these attributes show the strength of the company and hence, should be maintained well. The second quadrant is called head-to-head competition. Attributes located in this quadrant have low (negative) performance differences score but high (positive) gap scores. It means that though the focal company goes beyond the expectations of the customers for the service attributes in this quadrant, it has lower performance scores than the competitor. In this situation, the focal company should reach, at least, the competitor's performance level. Benchmarking with the best practice is suggested for the improvement as a part of continuous improvement. The third quadrant is in south-west, named urgent action. Attributes located in this quadrant have lower performance 
compared to the competitor (negative performance difference) and have poor performance than importance. The attributes represent the areas of weaknesses of the focal company; hence, it is necessary to take urgent action to improve them. Finally, the last quadrant is named null advantage. The attributes in this fourth quadrant have higher performance than the focal company's competitor (positive performance difference). Nevertheless, the expectations of the customers are not fulfilled by the performance of the attributes (i.e., the negative gap). This seems that the focal company seems to have a better performance than its competitor, but this is not a real advantage since the customers' expectations could not be exceeded.

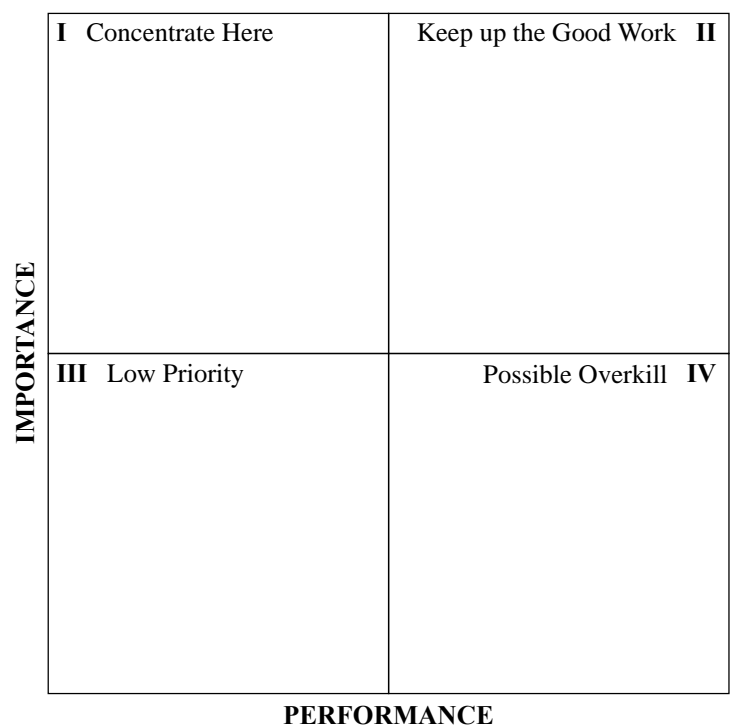

a. Typical IPA diagram

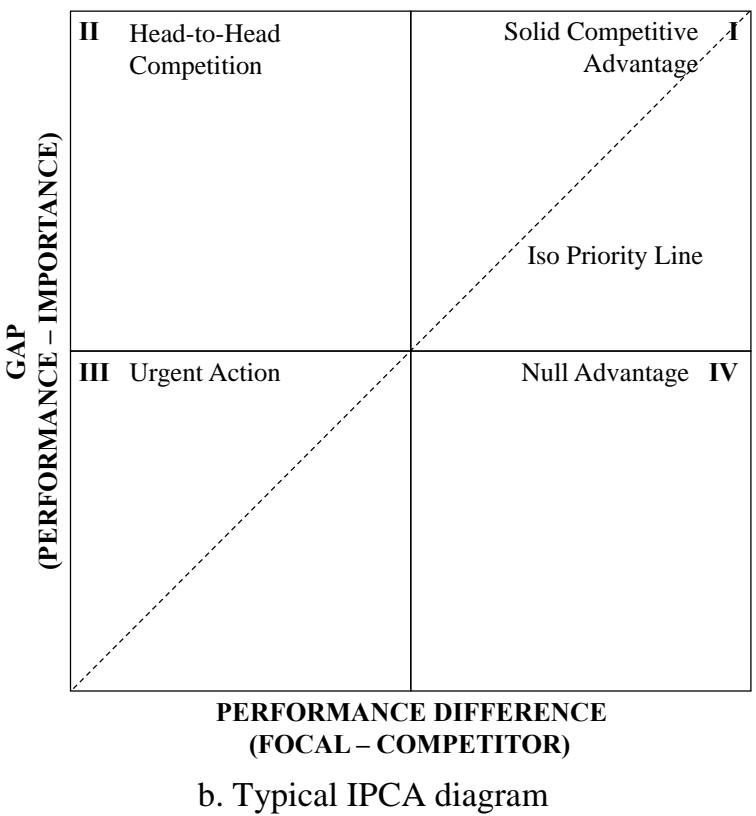

b. Typical IPCA diagram

Figure. 1. Typical IPA and IPCA diagrams

There are four quadrants in IPCA diagram. The first quadrant is in north-east, named solid competitive advantage. Attributes located in this quadrant both have high (positive) gap scores and high (positive) performance difference scores. It means that the focal company has better performance than its competitor, indicating that these attributes show the strength of the company and hence, should be maintained well. The second quadrant is called head-to-head competition. Attributes located in this quadrant have low (negative) performance differences score but high (positive) gap scores. It means that though the focal company goes beyond the expectations of the customers for the service attributes in this quadrant, it has lower performance scores than the competitor. In this situation, the focal company should reach, at least, the competitor's performance level. Benchmarking with the best practice is suggested for the improvement as a part of continuous improvement. The third quadrant is in south-west, named urgent action. Attributes located in this quadrant have lower performance compared to the competitor (negative performance difference) and have poor performance than importance. The attributes represent the areas of weaknesses of the focal company; hence, it is necessary to take urgent action to improve them. Finally, the last quadrant is named null advantage. The attributes in this fourth quadrant have higher performance than the focal company's competitor (positive performance difference). Nevertheless, the expectations of the customers are not fulfilled by the performance of the attributes (i.e., the negative gap). This seems that the focal company seems to have a better performance than its competitor, but this is not a real advantage since the customers' expectations could not be exceeded.

\section{RESUlT AND DISCUSSION}

A case study has been performed to measure and analyze customer satisfaction of an Indonesian-based logistics service company (called "focal company") against its competitor. The assessment has been carried out through an online questionnaire-based survey. It comprises of three parts. The first part deals with the demographic information of the respondents, such as gender, age, as well as occupation. The second part's 
intension is to identify the importance of each attribute from the respondent's perspective. The last part of the questionnaire aims to assess the performance of the focal company and its competitor. It is designed in a twocolumn format: the first is intended for the focal company and the second column is for its competitor.

The participants were required to have experience with both: the focal company and its competitor. All item statements were measured on a 5-point Likert-type scale, ranging from 1 (unimportant for importance-typed questions or the second part of the questionnaire and strongly disagree for performance-typed or the third part) to 5 (important for importance-typed questions and strongly agree for performance-typed questions). Thirty-nine respondents participated in this survey $(46.15 \%$ of them are male and $53.85 \%$ are female).

Scale purification was performed before analyzing the data. The principle that is used in determining whether to discard an attribute is the item's corrected item-to-total correlation. It is the correlation between the score on the item (or attribute) and the sum of scores on other attributes that constitute the dimension to which the attributes belong to (Parasuraman et al., 1988). The item-to-total correlations are charted in descending order for each dimension. Attributes with very low (and not statistically significant) correlations and/or those which have correlations produce a harsh drop in the charted pattern will be deleted. Fig. 2 shows the item-to-total correlations for each attribute in descending order. The calculation was carried out by employing IBM SPSS 25 . Note that all attributes have moderate-to-high correlations and statistically significant at the level of $1 \%$. In the end, there is no attribute which is discarded.

Table 1. Case study result

\begin{tabular}{|c|c|c|c|c|c|c|}
\hline Dimensions & Attributes & $\mathrm{P}_{i}$ & $\mathrm{I}_{i}$ & $\mathrm{PC}_{i}$ & $\operatorname{Gap}_{i}$ & $\mathrm{PD}_{i}$ \\
\hline \multirow{4}{*}{ Tangibles } & TAN1 & 3.487 & 4.538 & 4.128 & -1.051 & -0.641 \\
\hline & TAN2 & 3.846 & 4.359 & 4.077 & -0.513 & -0.231 \\
\hline & TAN3 & 4.128 & 4.641 & 4.231 & -0.513 & -0.103 \\
\hline & TAN4 & 3.846 & 4.410 & 4.051 & -0.564 & -0.205 \\
\hline \multirow{4}{*}{ Reliability } & REL1 & 3.923 & 4.872 & 3.769 & -0.949 & 0.154 \\
\hline & REL2 & 4.000 & 4.667 & 4.154 & -0.667 & -0.154 \\
\hline & REL3 & 4.385 & 4.692 & 3.718 & -0.308 & 0.667 \\
\hline & REL4 & 4.000 & 4.282 & 3.769 & -0.282 & 0.231 \\
\hline \multirow{4}{*}{ Responsiveness } & RES1 & 3.590 & 4.795 & 3.795 & -1.205 & -0.205 \\
\hline & RES2 & 3.949 & 4.590 & 4.051 & -0.641 & -0.103 \\
\hline & RES3 & 3.513 & 4.564 & 3.615 & -1.051 & -0.103 \\
\hline & RES4 & 3.949 & 4.769 & 3.872 & -0.821 & 0.077 \\
\hline \multirow{3}{*}{ Assurance } & ASS1 & 3.949 & 4.385 & 3.846 & -0.436 & 0.103 \\
\hline & ASS2 & 4.077 & 4.718 & 3.923 & -0.641 & 0.154 \\
\hline & ASS3 & 4.179 & 4.872 & 4.026 & -0.692 & 0.154 \\
\hline \multirow{3}{*}{ Empathy } & EMP1 & 3.769 & 4.615 & 4.051 & -0.846 & -0.282 \\
\hline & EMP2 & 4.051 & 4.641 & 4.103 & -0.590 & -0.051 \\
\hline & EMP3 & 4.000 & 4.564 & 3.949 & -0.564 & 0.051 \\
\hline
\end{tabular}




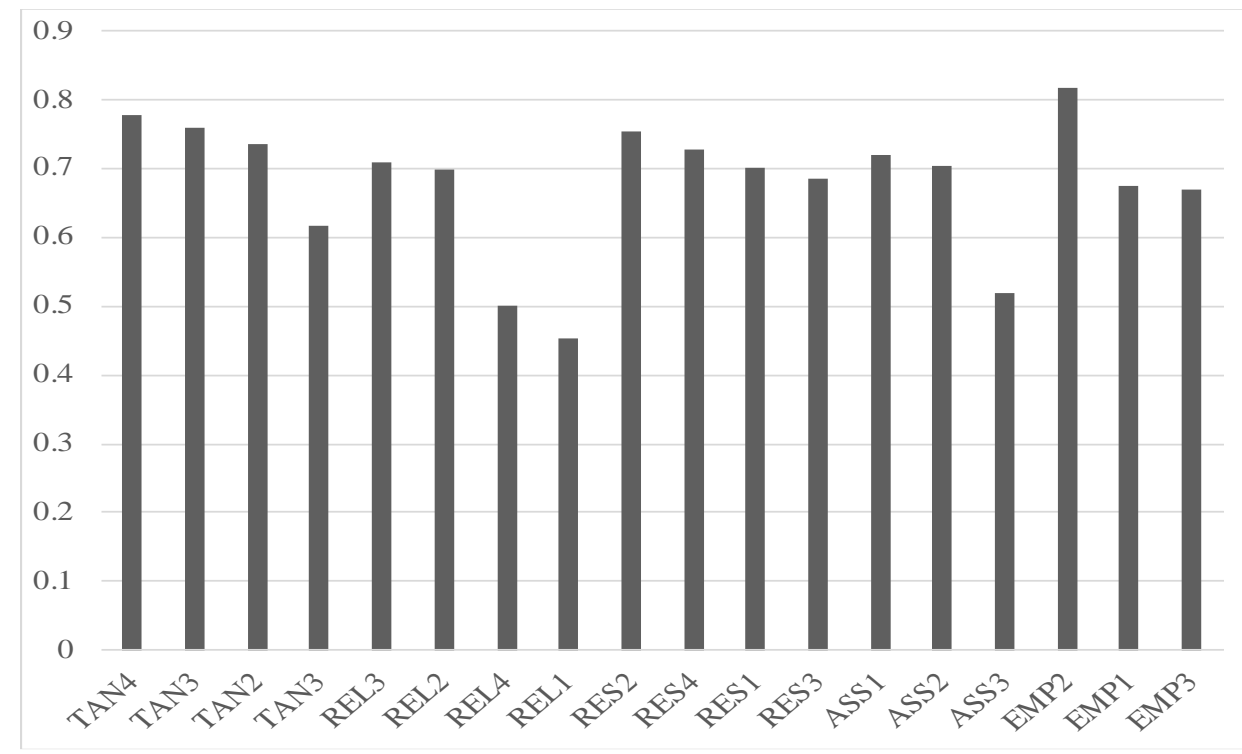

Figure. 2. Item-to-total correlation for each attribute

The valid attributes were then used to assess customer satisfaction using IPCA. Based on the calculation that has been performed, the scores of $\mathrm{P}_{i}, \mathrm{I}_{i}$, and $\mathrm{PC}_{i}$ for attribute $i$ are found by averaging all respondents' answers, e.g., $\mathrm{P}_{1}=\left(\sum_{j=1}^{N} p_{1 j}\right) / N$, where $N$ is the number of respondents, $p_{1 j}$ is the answer (performance of the focal company) from respondent $j$ for attribute 1 . (Similar method can be performed for calculating $\mathrm{I}_{i}$ and $\mathrm{PC}_{i}$.) $\mathrm{Gap}_{i}$ and $\mathrm{PD} i$ for attribute $i$ are found by subtracting $\mathrm{I}_{i}$ and $\mathrm{PC}_{i}$ (respectively) to $\mathrm{P}_{i}$, as has been explained previously. The complete result of this case study is depicted in Table 1. Note that all gaps are negative, indicating that the performance score for each attribute is lower that its corresponding importance. It also means that the focal company's service delivered to the customers cannot satisfy their expectation.

In the tangibles dimension, all attributes have negative scores for performance difference. It means that the performance of the focal company is worse than its competitor in terms of the cleanness and comfortability of the physical facilities, appearance of the employees, and the condition of the equipment used. Such condition is better in the reliability dimension, where only attribute REL2 is considered as having worse performance than the competitor. Tracking feature, time delivery, and alternative delivery option of the focal company does operate better than its competitor. In terms of responsiveness, only RES4 which has better performance; indicating that the competitor handles problems better and faster than the focal company, also, the employees (of the competitor) are very happy to help and respond to the customers' request compared to the focal company. In the empathy dimension, only EMP3 has positive value; meaning that the focal company's customer contact can be reached easier than its competitor. Finally, in the assurance dimension, the focal company is considered as having better performance in all attributes since all values of $\mathrm{PD}_{i} \mathrm{~s}$ are positive.

Previous results show that there are several aspects that need to improve because of having lower performance than the competitor. The focal company can use IPCA to create strategies to pursue customer satisfaction based on the performance and the importance of the service attributes from the customers' point of view. It has to be remembered that not all attributes need to be enhanced, since as a matter of fact, every company has limited resources. Therefore, it must be decided how those limited resources are used effective- and efficiently according to the priorities (or the importance) to achieve customer satisfaction. In this sense, IPCA (by the aid of IPCA diagram) is regarded as a suitable managerial tool to accomplish this objective.

In forming IPCA diagram, each service attribute is located on the diagram by employing the gap scores as a vertical axis (or $y$ coordinate) and PD scores as a horizontal axis (or $x$ coordinate). Two lines (vertical and horizontal) as crosshairs are then drawn from zero (i.e., value $=0$ ). Finally, IPCA diagram is divided into four quadrants and a strategic strategy can be found for each service attribute located on its position in the corresponding quadrant. IPCA diagram as a result of this case study is shown in Figure 3. 


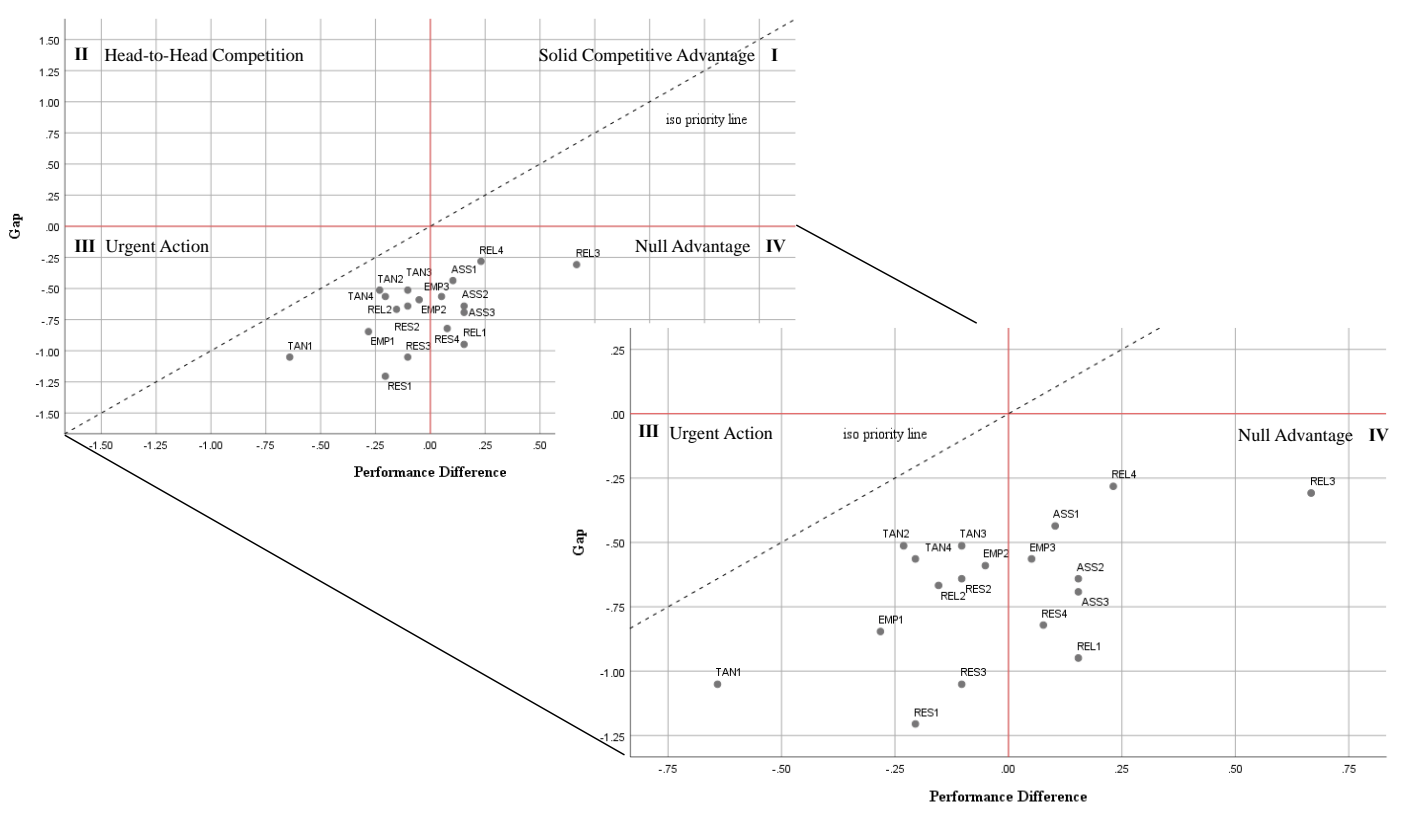

Figure 3. The result of IPCA diagram

Since all gap scores are negative, there is no attribute in the first and second quadrant. The attributes belong to the fourth quadrant are: RES4 from responsiveness dimension; REL1, REL3, REL4 from reliability dimension; all attributes from assurance dimension; EMP3 from empathy dimension; and no attribute from tangibles dimension. The management of the focal company should not be proud because these attributes are having better performance than the competitor. It is misleading! Although the performance is better, customer expectation still could not be fulfilled or even exceeded for these service attributes. (That is why this quadrant is named null advantage, since it is not the actual competitive advantage.) Ten attributes (i.e., all attributes from tangibles dimension; REL2 from reliability dimension; RES1, RES2, and RES3 from responsive-ness dimension; EMP1 and EMP2 from empathy dimension; and no attribute from assurance dimension) are in the third quadrant (urgent action). The quadrant is arguably the most important quadrant with respects to all quadrants. The attributes belong to this quadrant are having both negative gap and performance difference scores. It means that the focal company could not fulfil the expectation of the customers and having poor performance than the competitor. Those attributes are the focus of the focal company's improvement agenda to achieve the objective, i.e., customer satisfaction. For instance, the focal company must handle problems faster than its normal speed (RES1); the employees should give more personal attention to the customers because they might be not friendly enough when the customers come to them (EMP1).

We also tried to compare IPA and IPCA diagrams in terms of the position of each attribute on each quadrant (see Table 2) and present that results come from IPA diagram might lead to a misleading interpretation ${ }^{1}$. We have showed that attributes located in the third quadrant of IPCA must be improved by the management since they have lower performance scores than the competitor and also lower performance scores than the importance scores. However, in IPA diagram, these attributes spread on all over quadrants, i.e., in the first quadrant, concentrate here (RES1, EMP1), in the second quadrant, keep up the good work (TAN3, REL2, EMP2), in the third quadrant, low priority (TAN1, TAN2, TAN4, RES3), and in the last quadrant, possible overkill (RES2). It seems that only attribute RES1 and EMP1 would be improved if the management use IPA diagram to assess customer satisfaction. Contrarily, attributes located in other quadrants might not be improved by the management since the performance score is higher than the average score of all performance scores throughout all attributes (i.e., TAN3, REL2, and EMP2), or they are seen as not important by the customers (i.e., TAN1, TAN2, TAN4, RES3, and RES2).

\footnotetext{
IPA diagram is divided into four quadrants (see Fig. 1a). The attributes belong to the first quadrant have high importance scores, but the performance scores are low. To pursue customer satisfaction, the company is recommended to improve the performance of the attributes. Next, the attributes located in the second quadrant have high both for importance and performance scores, hence, they have to be preserved. The attributes belong to the third are observed as less important by the customers but perform well. Finally, the attributes located in the fourth quadrant should be downgraded by the management due to the unnecessary investment.
} 
Table 2. Comparison of the attribute position in the quadrant of IPCA and IPA diagrams

\begin{tabular}{|c|c|c|c|c|c|c|c|}
\hline Dimensions & Attributes & IPA & IPCA & Dimensions & Attributes & IPA & IPCA \\
\hline \multirow{4}{*}{ Tangibles } & TAN1 & III & III & \multirow{3}{*}{ Responsiveness } & RES2 & IV & III \\
\hline & TAN2 & III & III & & RES3 & III & III \\
\hline & TAN3 & II & III & & RES4 & II & IV \\
\hline & TAN4 & III & III & \multirow{3}{*}{ Assurance } & ASS1 & IV & IV \\
\hline \multirow{4}{*}{ Reliability } & REL1 & I & IV & & ASS2 & II & IV \\
\hline & REL2 & II & III & & ASS3 & II & IV \\
\hline & REL3 & II & IV & \multirow{3}{*}{ Empathy } & EMP1 & I & III \\
\hline & REL4 & IV & IV & & EMP2 & II & III \\
\hline Responsiveness & RES1 & I & III & & EMP3 & IV & IV \\
\hline
\end{tabular}

\section{CONCLUSION AND FUTURE RESEARCH DIRECTION}

The research has shown how to assess customer satisfaction of a logistics service company using IPCA. IPCA is considered better to handle inability of IPA by its absolute structured and considering the competitor. Case study's result indicated there are some attributes recommended to be improved due to having lower performance than the competitor. Those attributes belong to the "urgent action" quadrant on IPCA diagram. The method presented in this paper is regarded as inexpensive to implement, easy to interpret, and no necessity to have advanced level statistical knowledge.

Practically, this result of this study gives some recommendations for the business as well for the society. For the business, the result can give the management about what service attributes which need to be improved from the perspective of the customers. Note that the advantage of IPCA, like IPA, is that it only considers service attributes which have high importance relative to its performance. This feature is importance since every company is constrained by its limited resources. Due to this condition, the company must decide how those limited resources are best deployed to achieve the customer satisfaction. Moreover, unlike IPA, IPCA also considers the performance of the competitors. This feature enables company managers to evaluate their competitive ability relative to their competitors. Obtaining the competitor's performance information about the attributes may be hard to identify, however, the relative performance (i.e., better/worse than the competitors) might be easier to do (Slack, 1994). From the perspective of the society, i.e., the customers, if the company apply the method to improve their performance, it will lead to customer loyalty since the customers tend to use the service repeatedly. (As Cronin and Taylor, 1992; Ladhari et al., 2008 showed that excellent service precedes customer retention and leads to repeat customer purchase behavior.) This repeated usage of the service then could benefit to the company because it can increase the market share and generate high incomes as well (Luo and Homburg, 2007).

For the future research, it is suggested to combine the method with Kano model (Kano et al., 1984). The Kano model determines the categories of individual quality attributes based on customer satisfaction and dissatisfaction with how their individual requirements are catered to. This approach has been widely used to assess customer satisfaction (e.g., Rozaq et al., 2019; Velikova et al., 2017); however, it neglects the fact that quality attribute performance and importance can affect the results of categorization. Therefore, some scholars have attempted to integrate the Kano model with IPA (Kuo et al., 2012; Tseng, 2020). Due to the disadvantage of IPA as has been previously mentioned, the IPCA-Kano model could be an interesting area to be pursued.

\section{ACKNOWLEDGMENT}

The authors would like to thank to Ms. Wismar Rizki Wijayanti for her support of this research. 


\section{REFERENCES}

Abalo, J., Varela, J. and Manzano, V. (2007) 'Importance values for importance-performance analysis: A formula for spreading out values derived from preference rankings,' Journal of Business Research, Vol. 60, pp. $115-121$.

Albayrak, T. (2015) 'Importance performance competitor analysis (IPCA): A study of hospitality companies,' International Journal of Hospitality Management, Vol. 48, pp. 135-142.

Albayrak, T., Caber, M., González-Rodríguez, M. R. and Aksu, A. (2018) 'Analysis of destination competitiveness by IPA and IPCA methods: The case of Costa Brava, Spain against Antalya, Turkey,' Tourism Management Perspectives, Vol. 28, pp. 53-61.

Astari, F., Astari F., Kahfi, R. S., Ardi, F., Oki, L. and Ulkhaq, M.M. (2020) 'Service quality assessment of theme park,' in Proceedings of the 2nd International Conference on Management Science and Industrial Engineering, ACM, Osaka, Japan, pp. 49-53.

Bacon, D. R. (2003) 'A comparison of approaches to importance-performance analysis,' International Journal of Market Research, Vol. 45, No. 1, pp. 55-71.

Beldona, S. and Cobanoglu, C. (2007) 'Importance-performance analysis of guest technologies in the lodging industry,' Cornell Hotel and Restaurant Administration Quarterly, Vol. 48, No. 3, pp. 299-312.

Caber, M., Albayrak, T. and İsmayıllı, T. (2017) 'Analysis of congress destinations' competitiveness using importance performance competitor analysis,' Journal of Convention \& Event Tourism, Vol. 18, No. 2, pp. 100-117.

Chen, K. (2014) 'Improving importance-performance analysis: The role of the zone of tolerance and competitor performance. The case of Taiwan's hot spring hotels,' Tourism Management, Vol. 40, pp. 260-272.

Christopher, M. (1998) Logistics and Supply Chain Management: Strategies for Reducing Cost and Improving Service, Financial Times Pitman Publishing, London.

Chryssolouris, G. (2013) Manufacturing Systems: Theory and Practice, Springer, New York.

Crompton, J. L. and Duray, N. A. (1985) 'An investigation of the relative efficacy of four alternative approaches to importance-performance analysis,' Journal of the Academy of Marketing Science, Vol. 13, No. 4, pp. 69-80.

Cronin Jr, J. J. and Taylor, S. A. (1992) 'Measuring service quality: A reexamination and extension,' Journal of Marketing, Vol. 56, No. 3, pp. 55-68.

Hawes, J. M. and Rao, C. P. (1985), 'Using importance-performance analysis to develop health care marketing strategies,' Journal of Health Care Marketing, Vol. 5, No. 4, pp. 19-25.

Kano, N., Seraku, N., Takahashi, F. and Tsuji, S. (1984) 'Attractive quality and must-be quality,' Journal of Japanese Society for Quality Control, Vol. 14, No. 2, pp. 39-48.

Keyt, J.C., Yavas, U. and Riecken, G. (1994) 'Importance-performance analysis: A case Study in restaurant positioning,' International Journal of Retail \& Distribution Management, Vol. 22, No. 5, pp. 35-40.

Kuo, Y.-F., Chen, J.-Y. and Deng, W.-J. (2012) 'IPA-Kano model: A new tool for categorising and diagnosing service quality attributes,' Total Quality Management \& Business Excellence, Vol. 23, No. 7-8, pp. 731748 ,

Ladhari, R., Brun, I. and Morales, M. (2008) 'Determinants of dining satisfaction and post-dining behavioral intentions,' International Journal of Hospitality Management, Vol. 27, pp. 563-573.

Langley, J. Jr. (2012) 2013 Third-party logistics study: The state of logistics outsourcing. Results and findings of the 13th annual study [online] https://www.capgemini.com/resource-file-access/ resource/pdf/2013_Third-Party_Logistics_Study.pdf/.

Lai, I. K. W. and Hitchcock, M. (2015) 'Importance-performance analysis in tourism: A framework for researchers,' Tourism Management, Vol. 48, pp. 242-267.

Luo, X. and Homburg, C. (2007) 'Neglected outcomes of customer satisfaction,' Journal of Marketing, Vol. 71, pp. 133-149.

Martilla, J. A. and James, J. C. (1977) 'Importance-performance analysis,' Journal of Marketing, Vol. 41, No. 1, pp. 77-79. 
Mikulić, J., Prebežac, D. (2012) 'Accounting for dynamics in attribute-importance and for competitor performance to enhance reliability of BPNN-based importance-performance analysis,' Expert Systems with Applications, Vol. 39, No. 5, pp. 5144-5153.

Myers, J. H. and Alpers, M. I. (1968) 'Determining attributes: Meaning and measurement,' Journal of Marketing, Vol. 32, No. 4, pp. 13-20.

Oh, H. (2001) 'Revisiting importance-performance analysis,' Tourism Management, Vol. 22, pp. 617-627.

Parasuraman, A., Zeithaml, V. A. and Berry, L. L. (1988) 'SERVQUAL: A multiple-item scale for measuring consumer perceptions of service quality,' Journal of Retailing, Vol. 64, pp. 12-40.

Pramono, S. N. W., Ulkhaq, M. M., Trianto, R., Rasyida, D. R., Setyorini, N. A., Setiowati, P. R. and Jauhari, W. A. (2017) 'Integrating the analytic hierarchy process and importance-performance analysis into ISO 14001 framework for assessing campus sustainability,' AIP Conference Proceedings, Vol. 1902, p. 020035.

Rasyida, D. R., Ulkhaq, M. M., Setiowati, P. R. and Setyorini, N. A. (2016) 'Assessing service quality: A combination of SERVPERF and importance-performance analysis,' MATEC Web of Conferences, Vol. 68, p. 06003.

Rozaq, R., Larasati, D. M., Tampubolon, D. H., Ramadhani, R. and Ulkhaq, M. M. (2019) 'An application of the Kano model for assessing customer satisfaction of hospital service quality,' in Proceedings of the 6th International Conference on Industrial Engineering and Applications, IEEE, Tokyo, Japan, pp. 278-283.

Ruiz-de-Arbulo-Lopez, P., Fortuny-Santos, J. and Cuatrecasas-Arbós, L. (2013) 'Lean manufacturing: Costing the value stream,' Industrial Management \& Data Systems, Vol. 113, No. 5, pp. 647-668.

Sampsona, S. E. and Showalter, M. K. (1999) 'The performance-importance response function: observations and implications,' The Service Industries Journal, Vol. 19, No. 3, pp. 1-25.

Silva, F. and Fernandes, P. (2010) 'Using importance-performance analysis in evaluating institutions of higher education: A case study,' in Proceedings of the International Conference on Education and Management Technology, IEEE, pp. 121-123.

Slack, N. (1994) 'The importance-performance matrix as a determinant of improvement priority,' International Journal of Operations \& Production Management, Vol. 14, No. 5, pp. 59-75.

Swan, J. G. and Coombs, L. J. (1976) 'Product performance and consumer satisfaction: A new concept,' Journal of Marketing, Vol. 40, No. 2, pp. 25-33.

Tonge, J. and Moore, S. A. (2007) 'Importance satisfaction analysis for marine park hinterlands: A Western Australian case study,' Tourism Management, Vol. 28, pp. 768-776.

Tontini, G. and Silveira, A. (2007) 'Identification of satisfaction attributes using competitive analysis of the improvement gap,' International Journal of Operations \& Production Management, Vol. 27, No. 5, pp. 482-500.

Tseng, C. C. (2020) 'An IPA-Kano model for classifying and diagnosing airport service attributes,' Research in Transportation Business \& Management, p. 100499.

Ulkhaq, M. M, Widodo, A. K., Widhiyaningrum, Yulianto, M. F. A. and Gracia, M. O. (2019a) 'An integrated M-S-QUAL and importance-performance analysis approach for assessing service quality of mobile commerce application,' AIP Conference Proceedings, Vol. 2114, p. 060001.

Ulkhaq, M. M., Rabbani, M., Rachmania, B. A., Wibowo, A. T. and Ardi, F. (2019b) 'Integrating importanceperformance analysis into E-S-QUAL and E-RecS-QUAL scales for assessing electronic service quality, IOP Conference Series: Materials Science and Engineering, Vol. 598, p. 012002.

Ulkhaq, M. M., Wijayanti, W. R., Kusumawati, A., Aulia, F. S., Wijayanti, R. S. and Wiganingrum, R. (2017) 'Combining the eTransQual scale and importance-performance analysis to assess service quality of online shopping,' in Proceedings of the 4th International Conference on Industrial Engineering and Applications, IEEE, Nagoya, Japan, pp. 146-150.

Velikova, N., Slevitch, L. and Mathe-Soulek, K. (2017) 'Application of Kano model to identification of wine festival satisfaction drivers,' International Journal of Contemporary Hospitality Management, Vol. 29, No. 10, pp. 2708-2726. 
Yu, C.S. (2008) 'Assessing and differentiating the quality of Internet-based services: A case of online banking in Taiwan,' The Service Industries Journal, Vol. 28, No. 5, pp. 581-602. 